\title{
Measuring organ dysfunction in the intensive care unit: why and how?
}

John C. Marshall MD FRSCS

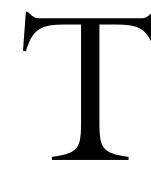

HE phenomenon that has come to be known as the multiple organ dysfunction syndrome $(\mathrm{MODS})^{1}$ was first described 35 years ago. ${ }^{2}$ In a report emanating from a study of critically ill surgical patients in Boston, Skillman and his colleagues suggested that the spectrum of life-threatening complications that defined the clinical course of the sickest patients could be considered a syndrome - a manifestation of a common underlying pathologic process, rather than a random constellation of unrelated bits of bad luck. This notion was further developed by Baue, who argued that in the absence of overwhelming neurologic injury, death in the intensive care unit (ICU) was rarely the result of the irreversible failure of any one organ system, but rather reflected the interactive effects of multiple systems whose activities were functionally interdependent; he termed this problem "multiple, progressive, or sequential systems failure". ${ }^{3}$ Subsequent efforts to quantify the extent and clinical burden of this newly defined syndrome suggested that it was the leading cause of morbidity and mortality in contemporary critical care practice, and responsible for at least $80 \%$ of all ICU deaths. ${ }^{4}$

In a trivial sense, the construct of MODS can be viewed as an ostentatious expression of the truism that the ICU patients who are most likely to die are those who are sickest. And by calibrating organ dysfunction measurement scales against ICU mortality, the developers of these scales have lent credibility to this interpretation. But from the earliest clinical descriptions of the phenomenon, it has been apparent that patients who develop MODS share common risk factors such as overwhelming infection, ${ }^{5}$ multiple trauma, ${ }^{6}$ ischemia/reperfusion injury, ${ }^{7}$ or sterile inflammation, ${ }^{8}$ all of which, in turn, share a mechanistic basis in the activation of a systemic inflammatory response. If the clinical features of the systemic inflammatory response syndrome can be seen as the systemic expression of the cardinal manifestations of local inflammation - rubor (vasodilatation), calor (fever), dolour (pain and altered mentation), and tumour (edema and increased capillary permeability)- then remote organ dysfunction or MODS is the functio laesa of systemic inflammation. ${ }^{9}$ In attempting to describe MODS, we are not primarily trying to intuit which critically ill patients will die and which will survive, but rather to describe the divergent dimensions of a poorly-defined syndrome that develops in many critically ill patients, that arises through the activation of an innate immune response, and that necessitates ICU supportive care. Description, rather than prognostication, is the primary objective, although a valid descriptor of a lethal disease process will of necessity have prognostic value.

In this issue of the journal, ${ }^{10}$ Zygun and his colleagues in Calgary have taken advantage of the tremendous data management capacity of an electronic patient information system to compare two commonly used tools for measuring organ dysfunction the Sequential Organ Failure Assessment (SOFA) score developed through a consensus process by the European Society of Intensive Care Medicine in $1994,{ }^{11}$ and the Multiple Organ Dysfunction (MOD) score, a Canadian scale developed in the late 1980's and early 1990's, using an iterative process that sought to maximize construct, content, and criterion validity. ${ }^{12,13}$ They conclude that there is little difference between the two scales in their ability to discriminate outcome, and that neither performs particularly well when evaluated on the basis of their discriminatory ability and calibration. They found that the cardiovascular component of SOFA is better able to discriminate survivors and non-survivors, but conclude that the poor performance characteristics of both throw into question the use of organ dysfunction measures as surrogate outcomes in clinical trials.

From the Department of Surgery and the Interdepartmental Division of Critical Care Medicine, University of Toronto, Toronto, Ontario, Canada.

Address correspondence to: Dr. John C. Marshall, Toronto General Hospital, University Health Network, 200 Elizabeth Street, Eaton North 9-234, Toronto M5G 2C4, Ontario, Canada. Phone: 416-340-5204; Fax: 416-595-9486; Email: John.Marshall@uhn.on.ca 
I agree. The questions that we must then address are what are we trying to measure, why, and how can we do this better. This is no trivial charge.

Let us first consider the question of what an organ dysfunction score should seek to measure. Sophisticated prognostic scales have been developed to quantify an individual patient's risk of mortality early during the ICU stay. ${ }^{14,15}$ These scales have been developed using an approach that maximizes prognostic capacity, but makes no attempt to describe why or how the patient died; in the parlance of measurement methodologies, they are calibrated exclusively against criterion validity, and ignore construct validity. A robust prognostic score should be able to forecast the demise of an ICU patient whether that patient died of complications of diffuse peritonitis from a gunshot wound to the abdomen or a massive pulmonary embolus. A key insight provided through the development of scores such as APACHE and SAPS is that this early risk is driven by three factors - the severity of the early, acute physiologic derangement, the pre-morbid health status, and the age of the patient; the former reflects the initial severity of the acute insult, the latter, the physiologic reserve of the patient. Organ dysfunction scores, on the other hand, seek to describe where the patient ends up after resuscitation, and how this state of organ system insufficiency evolves over time. If organ dysfunction is lethal, then a valid scale will have prognostic capacity. However by focusing on post-resuscitation events using the construct of organ dysfunction, a valid organ dysfunction scale should be inferior in performance to a prognostic score. It should predict that a patient with an exsanguinating bleed, a massive pulmonary embolus, or an acute irreversible arrhythmia should live, not because it lacks discrimination, but because it does not measure death when it arises from causes other than those that result from an activated inflammatory response and that conform to the disorder seen by the clinician as MODS. In other words, it should measure organ dysfunction when the clinical syndrome is present, but not when it is absent, even though the patient may live in the former case, and die in the latter.

This of course begs the question of when is MODS present, and how do we recognize it? The MOD score addressed this challenge through a systematic review of the literature to identify which systems, and what abnormalities in those systems, defined organ dysfunction; the SOFA score approached the question through an expert consensus conference of intensivists. Although these were not strictly independent initiatives, both came up with a scale that incorporated the same six systems, using largely the same variables to describe organ dysfunction. There were several differences. The MOD score used only physiologic variables, and intentionally ignored the effects of treatment (an assumption that was found to have only a very modest effect on classification), while the SOFA score incorporated both physiologic measures and measures of therapeutic intervention - the need for mechanical ventilation and the use of inotropes, for example. This distinction led to the key perceived difference between the two. SOFA measures cardiovascular dysfunction based on the dose of vasopressor therapy employed, whereas the MOD score developed a new variable - the pressure-adjusted rate, calculated as the product of the heart rate and central venous pressure (CVP), divided by the mean arterial pressure - to describe cardiovascular function in physiologic, and treatment-independent terms. While the variable is novel, and therefore unfamiliar, it is actually simple to calculate, and analogous to the $\mathrm{PO}_{2} / \mathrm{FIO}_{2}$ ratio in that it corrects physiology for the consequences of therapy. Moreover, it can be calculated even in the patient who lacks a CVP monitor by assigning a normal CVP value, for example 8 , to such patients. Increasing values reflect worsening organ dysfunction, and increasing values occur as the heart rate increases, the mean arterial pressure falls, or the CVP increases. In other words, a high value will result if tachycardia and hypotension persist despite adequate volumeloading - the classic description of refractory shock.

Which brings us to the second question - why do we want to measure organ dysfunction? All the proponents of organ dysfunction scales agree that the rationale for measuring organ dysfunction is not to predict who will live and who will die, but rather to describe morbidity as it evolves over time, using the construct of organ dysfunction. But how do we measure whether or not we are accomplishing this objective? Metrics such as discrimination and calibration that have become popular for evaluating prognostic scores are of much less use in evaluating the performance of organ dysfunction scores because there is no gold standard against which to evaluate performance. In the absence of objective metrics, we must instead try to determine what we want to know, and then determine whether the scale is providing that information - a very subjective, and methodologically unsatisfying approach. For example, it was an initial expectation of the developers of organ dysfunction scales that by capturing discrete domains of morbidity, using sensitive and continuous variables, an organ dysfunction score would be a more sensitive outcome measure than mortality, and so would permit studies to obtain definitive answers using smaller sample sizes. Experience has shown that this expectation was mis- 
taken, and that organ dysfunction scores are no more sensitive than 28-day mortality in detecting an overall treatment effect. ${ }^{16,17}$ However organ dysfunction scales may well be able to provide insights that aid in understanding the nature of that treatment effect, and so aid in tailoring treatment to specific subpopulations of patients in the heterogeneous population of critically ill patients that meets the entry criteria for sepsis trials. ${ }^{18}$ Thus the mortality benefit may vary with the degree of organ dysfunction at baseline, ${ }^{19}$ and identification of the specific systems where differential effect is the greatest and the time course over which the effect is seen ${ }^{18}$ may provide insight into which patients are most likely to benefit, and how long treatment should be given. Of course this is hypothesis, not catechism, and much work needs to be done to determine how best to use these measurement tools.

Which brings us to the third question - how can we do better? For a start, we need to understand the differences between scales, and to determine whether one approach is superior, or alternatively, whether two different, but informative facets of a question are being addressed. For example, SOFA employs the worst values obtained on a given day, MODS, a representative value; this difference should, on average, result in SOFA showing a stronger correlation with death. But which approach captures the essence of the clinical course we are trying to measure? MODS uses exclusively physiologic variables, whereas SOFA uses both physiologic and therapeutic variables. Physiology and therapy are intimately related in the ICU, but I believe that their measurement should be carefully differentiated, both because approaches to therapy vary, but even more importantly, because we are learning that therapy can contribute to organ dysfunction in the ICU. ${ }^{16,20}$ Suppose, for example, we had defined hematologic failure as the need for transfusion of red blood cells. Prior to the TRICC trial we would have assumed that transfusion was an independent measure of morbidity; on the basis of that trial, we now understand that transfusion is also a cause of that morbidity. ${ }^{16}$ Similarly if we had defined respiratory failure by the ventilatory parameters used to secure adequate oxygenation, we would have concluded that high tidal volumes were a reflection of organ dysfunction, rather than a cause..$^{20}$ Does the fact that the dose of vasopressor in the SOFA score correlated better with mortality than the pressure-adjusted heart rate of the MOD score reflect the superior performance of the variable, or an adverse consequence of a clinical intervention? Physiologic variables provide the most reliable measures of a biologic effect, and it is for this reason that the MOD score incorporates only physio- logic variables. But physiologic variables say nothing about the more important patient-centred outcomes. A critically ill patient is oblivious to his $\mathrm{PO}_{2} / \mathrm{FIO}_{2}$ ratio, but not to the fact that a ventilator is being used to achieve that physiologic goal. She has no interest whatsoever in her creatinine level, but the need for dialysis poses a major burden on her quality of life. There clearly is a need for parallel measures of events that impact on patient well-being, but how are therapeutic variables best selected and calibrated?

The development of organ dysfunction scales is an enterprise in its infancy. It poses numerous challenges, from acquisition of data, to delineation of the precise objectives of measurement, to development of optimal metrics for evaluation of performance. Zygun and his colleagues have identified some of the challenges, and have shown that the first objective can be accomplished effectively through the use of patient data management systems. Measuring what we treat and what we do is a fundamental, but vastly under-developed aspect of critical care practice, and a pre-requisite to optimizing therapy in a vulnerable, and enormously complex group of patients. The critical care community must embrace this challenge, and move forward to develop the next generation of these measurement tools.

\section{Évaluer la dysfonction organique à l'unité des soins intensifs : pourquoi et comment ?}

Le phénomène, devenu le syndrome de défaillance multiviscérale $(S D M V)^{1}$, a été décrit pour la première fois il y a 35 ans. $^{2}$ Dans un article émanant d'une étude faite à Boston auprès de patients de chirurgie gravement malades, Skillman et ses collègues ont proposé que l'ensemble des complications virtuellement mortelles observées soit considéré comme un syndrome - la manifestation d'un processus pathologique courant sous-jacent, plutôt qu'une multitude de malchances non reliées. Baue alla plus loin en affirmant qu'en l'absence de lésion neurologique importante, la mort à l'unité des soins intensifs (USI) résultait rarement de la défaillance irréversible d'un organe ou d'un système, mais des effets interactifs de 
nombreux systèmes dont les activités sont fonctionnellement interdépendantes; il nomme ce problème «défaillance systémique multiple, progressive ou séquentielle».3 Puis, en cherchant à quantifier l'étendue et la charge clinique du syndrome nouvellement défini, on a constaté qu'il était la principale cause de morbidité et de mortalité en pratique contemporaine des soins intensifs et responsable d'au moins $80 \%$ de tous les décès à l'USI. ${ }^{4}$

Selon le sens commun, le concept de SDMV serait l'exagération d'un truisme : les patients de l'USI les plus susceptibles de mourir sont les plus grands malades. En calibrant les échelles de mesure de la dysfonction organique selon la mortalité à l'USI, les promoteurs de ces échelles ont donné du crédit à cette interprétation. Depuis les premières descriptions cliniques du SDMV, on observa que les patients atteints présentaient des facteurs de risque communs, comme une infection invalidante, ${ }^{5}$ de multiples traumas,${ }^{6}$ une lésion d'ischémie/reperfusion ${ }^{7}$ ou une inflammation stérile $^{8}$, dont chacun, pour leur part, partageait une base mécaniste dans l'activation d'une réaction inflammatoire généralisée. Si le portrait clinique de cette réaction peut être vu comme l'expression générale des manifestations essentielles de l'inflammation locale rubor (vasodilatation), calor (fièvre), dolor (douleur et altération de l'état mental) et tumor (œdème et perméabilité capillaire accrue) - la dysfonction organique ou le SDMV est alors la functio laesa de l'inflammation généralisée. ${ }^{9}$ En décrivant le SDMV, nous n'essayons pas d'abord de deviner intuitivement quels grands malades vont mourir ou survivre, mais plutôt de présenter les dimensions divergentes d'un syndrome mal défini qui se développe chez des patients gravement atteints, qui survient par l'activation d'une réaction immunitaire innée et qui nécessite des soins de soutien à l'USI. La description est l'objectif principal, plutôt que le pronostic, bien qu'un descripteur valide du processus lésionnel mortel aura nécessairement une valeur pronostique.

Dans le présent numéro du journal, ${ }^{10}$ Zygun et ses collègues de Calgary ont tiré avantage de la formidable capacité de gestion des données d'un réseau d'information électronique sur les patients pour comparer deux outils de mesure de la dysfonction organique couramment utilisés - le Sequential Organ Failure Assessment (SOFA) score développé à partir d'un consensus par la European Society of Intensive Care Medicine en 1994, ${ }^{11}$ et le Multiple Organ Dysfunction $(M O D)$ score, échelle canadienne élaborée à la fin des années 1980 et au début des années 1990, en utilisant un processus itératif qui tente de maximiser la validité du construit, du contenu et des critères. ${ }^{12,13}$ Il existe, selon eux, une petite différence entre les deux échelles quant à la capacité de caractériser les résultats, mais aucune ne fonctionne particulièrement bien quand on les évalue sur leur capacité discriminante et leur calibrage. De plus, la composante cardiovasculaire du SOFA peut mieux distinguer ceux qui vont survivre ou non, mais la pauvreté des indices de performance des deux échelles remettent en question l'usage de mesures de la dysfonction organique comme paramètre suppléant dans les essais cliniques.

Je suis d'accord. Maintenant, demandons-nous ce que nous essayons de mesurer, puis, pourquoi et comment pouvons-nous le faire mieux ? Ce n'est pas une mince tâche.

D'abord, qu'est-ce qu'un score de dysfonction organique devrait chercher à mesurer ? Des échelles diagnostiques complexes ont été élaborées pour quantifier le risque de mortalité chez un patient donné pendant son séjour à l'USI. ${ }^{14,15}$ Le développement de ces échelles s'est fait en maximisant la capacité pronostique, mais sans chercher à décrire pourquoi ou comment le patient meurt ; en termes de méthodologies de mesure, leur calibrage est exclusivement fait en fonction de la validité des critères sans tenir compte de la validité du construit. Un score pronostique solide devrait permettre de prévoir le décès d'un patient de l'USI, que ce dernier meure des complications d'une péritonite diffuse, consécutive à une blessure par balle à l'abdomen, ou d'une embolie pulmonaire massive. Un aspect clé fourni par le développement des scores comme APACHE et SAPS est que ce risque primaire dépend de trois facteurs - la sévérité du premier dérèglement physiologique aigu, l'état de santé prémorbide et l'âge du patient; le premier indique la sévérité initiale de l'atteinte aiguë, le dernier, la réserve physiologique du patient. Par ailleurs, les scores de dysfonction organique tentent de décrire où se retrouve le patient après la réanimation et comment l'insuffisance organique évolue avec le temps. Si la dysfonction est mortelle, une échelle valide aura alors une capacité pronostique. Cependant, si on se concentre sur les événements postréanimation, en utilisant le construit de la dysfonction organique, une échelle valide de dysfonction organique serait inférieure en performance à un score pronostique. Elle devrait prédire si un patient victime d'une hémorragie massive, d'embolie pulmonaire marquée ou d'arythmie aiguë irréversible pourra vivre, non par son manque de discrimination, mais parce qu'elle ne mesure pas la mort provoquée par des causes autres que celles qui résultent d'une réaction inflammatoire activée et qui sont conformes au désordre observé par le clinicien et surnommé le SDMV. En d'autres mots, elle devrait 
mesurer la dysfonction organique quand le syndrome clinique est présent, mais non quand il est absent, même si le patient peut vivre dans le premier cas, et mourir dans le second.

Bien sûr, cela ne dit pas quand le SDMV est présent et comment le reconnaître ? Le score de DMV a relevé le défi après une revue systématique des publications afin de repérer les systèmes, et les anomalies de ces systèmes, qui définissent la dysfonction organique; le score SOFA a été développé d'après un consensus d'experts intensivistes. Ces initiatives, non totalement indépendantes, sont toutes deux arrivées à une échelle qui comportait les six mêmes systèmes utilisant à peu près les mêmes variables pour décrire la dysfonction organique, à quelques différences près. Ainsi, le score de DMV a utilisé seulement des variables physiologiques et a volontairement mis de côté les effets du traitement (une hypothèse qui s'est révélée n'avoir qu'un très modeste effet sur la classification), tandis que le score SOFA a tenu compte des mesures physiologiques et thérapeutiques - la nécessité d'une ventilation mécanique et l'usage d'inotropes, par exemple. C'est la différence clé perçue entre les deux scores. Le SOFA mesure la dysfonction cardiovasculaire sur la dose de vasopresseurs employée, tandis que le score de DMV a introduit une nouvelle variable - la fréquencepression ajustée, calculée comme le produit de la fréquence cardiaque par la pression veineuse centrale (PVC) divisé par la tension artérielle moyenne - pour décrire la fonction cardiovasculaire en termes physiologiques et indépendants du traitement. La variable est nouvelle, donc inconnue, mais simple à calculer et analogue au ratio $\mathrm{PO}_{2} / \mathrm{FIO}_{2}$ en ce qu'elle corrige la physiologie selon les conséquences du traitement. Et qui plus est, on peut la calculer même chez le patient qui n'est pas sous moniteur de PVC en lui assignant une valeur normale de PVC, 8 par exemple. Des valeurs plus élevées annoncent une aggravation de la dysfonction organique et se manifestent par une hausse de la fréquence cardiaque, une chute de la tension artérielle moyenne ou une élévation de la PVC. Autrement dit, il y aura une valeur élevée si la tachycardie et l'hypotension persistent malgré une charge volumique adéquate - description classique du choc réfractaire.

Ce qui nous amène à la deuxième question pourquoi voulons-nous mesurer la dysfonction organique? Tous les partisans des échelles de dysfonction organique disent que l'idée n'est pas de prédire qui vivra et qui mourra, mais plutôt de décrire la morbidité et son évolution dans le temps en utilisant le construit de la dysfonction organique. Mais comment mesurer l'atteinte d'un tel objectif ? Les paramètres comme la caractérisation et le calibrage, maintenant populaires pour évaluer les scores pronostiques, sont beaucoup moins utiles pour évaluer la performance des scores de dysfonction organique parce qu'il n'y a pas de point de référence à partir duquel on peut mesurer la performance. En l'absence de données objectives, il faut plutôt essayer de déterminer ce que nous voulons savoir et, vérifier ensuite si l'échelle fournit cette information - une méthode très subjective et méthodologiquement insatisfaisante. Par exemple, les développeurs d'échelles de dysfonction organique ont d'abord cru qu'en saisissant des domaines discrets de morbidité, par des variables sensibles et continues, un score de dysfonction organique serait une mesure de résultat plus sensible que la mortalité et qu'il servirait à réaliser des études pour obtenir des réponses définitives à partir de plus petits échantillons. L'expérience a montré que c'était une erreur et que les scores de dysfonction organique ne sont pas plus sensibles que la mortalité à 28 jours pour détecter un effet global du traitement. ${ }^{16,17}$ Cependant, les échelles de dysfonction organique pourraient bien laisser entrevoir ce qui aide à comprendre la nature de cet effet thérapeutique et à adapter le traitement à des sous-populations de patients spécifiques parmi l'hétérogénéité des grands malades qui répondent aux critères d'inclusion à des essais sur la septicémie. ${ }^{18}$ Le bénéfice qu'on retire à utiliser le critère de mortalité peut donc varier avec le degré de dysfonction organique de départ. ${ }^{19}$ Aussi, la désignation des systèmes spécifiques où l'effet différentiel a été le plus important et la description de l'évolution menant à l'observation de l'effet ${ }^{18}$ pourraient donner une idée des patients les plus susceptibles d'en profiter et de la durée idéale du traitement. Ce n'est bien sûr qu'une hypothèse, pas un catéchisme. Beaucoup de travail reste à faire pour découvrir comment mieux utiliser ces outils de mesure.

Ce qui nous amène à la troisième question - comment faire mieux ? D'abord, il faut comprendre les différences entre les échelles et vérifier si une méthode est supérieure ou si deux facettes d'une question, différentes mais informatives, sont abordées. Par exemple, le SOFA emploie les pires valeurs obtenues un jour donné, alors que le SDMV utilise une valeur représentative ; cette différence devrait, en moyenne, produire un SOFA qui montre une forte corrélation avec un décès. Mais quelle méthode saisit l'essence de l'évolution clinique que nous tentons de mesurer ? Le SDMV utilise exclusivement des variables physiologiques, et le SOFA, des variables physiologiques et thérapeutiques. La physiologie et la thérapie sont intimement liées à l'USI, mais je crois que leur mesure 
doit être soigneusement différenciée, parce que les approches du traitement varient, mais surtout, parce que nous apprenons que le traitement peut contribuer à la dysfonction organique à l'USI. ${ }^{16,20}$ Supposons, par exemple, que nous ayons défini l'insuffisance hématologique comme la nécessité d'une transfusion de culots globulaires. Avant l'essai, nous aurions présumé que la transfusion était une mesure indépendante de la morbidité ; nous savons maintenant, après cette étude, que la transfusion est aussi une cause de la morbidité. ${ }^{16}$ De même, si nous avions défini l'insuffisance respiratoire par les paramètres ventilatoires utilisés pour assurer une oxygénation adéquate, nous aurions conclu que les volumes courants élevés montraient une dysfonction organique plutôt qu'une cause. $^{20}$ Le fait que la dose de vasopresseurs du score SOFA était mieux corrélée à la mortalité que la fréquence-pression ajustée ne l'était au score de DMV indique-t-il la performance supérieure de la variable ou une conséquence indésirable d'une intervention clinique ? Les variables physiologiques donnent les mesures les plus fiables de l'effet biologique et c'est pourquoi le score de DMV ne compte que des variables physiologiques. Ces dernières ne disent pourtant rien des plus importants résultats centrés sur le patient. Une malade gravement atteinte n'est pas consciente du ratio $\mathrm{PO}_{2} / \mathrm{FIO}_{2}$, mais elle sait qu'un ventilateur est utilisé pour atteindre cet objectif physiologique. Elle n'a aucun intérêt non plus dans son niveau de créatinine, mais le besoin de dialyse pèse lourd sur sa qualité de vie. Il y a clairement une nécessité de mesures parallèles d'événements qui agissent sur le bien-être du patient, mais comment les variables thérapeutiques sont-elles mieux sélectionnées et calibrées ?

L'élaboration d'échelles de dysfonction organique n'en est qu'à ses débuts. Elle pose de nombreux défis, allant de l'acquisition des données à la détermination d'objectifs précis de mesure jusqu'au développement de paramètres optimaux d'évaluation de la performance. Zygun et ses collègues ont reconnu certains défis et montré que notre premier objectif peut être atteint efficacement à l'aide des systèmes de gestion de données sur les patients. Mesurer ce que nous traitons et ce que nous faisons est un aspect fondamental, mais grandement sous-développé, de la pratique des soins intensifs et un prérequis au traitement optimal chez un groupe variable de patients très vulnérables. Les intervenants des soins intensifs doivent relever ce défi et poursuivre leur avancée vers la nouvelle génération d'outils de mesure.

\section{References}

1 Bone RC, Balk RA, Cerra FB, et al. Definitions for sepsis and organ failure and guidelines for the use of innovative therapies in sepsis. Chest 1992; 101: 1644-55.

2 Skillman JJ, Bushnell LS, Goldman H, Silen W. Respiratory failure, hypotension, sepsis, and jaundice. A clinical syndrome associated with lethal hemorrhage and acute stress ulceration of the stomach. Am J Surg 1969; 117: 523-30.

3 Bane AE. Multiple, progressive, or sequential systems failure. A syndrome of the 1970s. Arch Surg 1975; 110: 779-81.

4 Deitch EA. Multiple organ failure. Pathophysiology and potential future therapy. Ann Surg 1992; 216: 117-34.

5 Fry DE, Pearlstein L, Fulton RL, Polk HC Jr. Multiple system organ failure. The role of uncontrolled infection. Arch Surg 1980; 115: 136-40.

6 Faist E, Bane AE, Dittmer H, Heberer G. Multiple organ failure in polytrauma patients. J Trauma 1983; 23: 775-87.

7 Tilney NL, Bailey GL, Morgan AP. Sequential system failure after rupture of abdominal aortic aneurysms: an unsolved problem in postoperative care. Ann Surg 1973; 178: 117-22.

8 Le Mee J, Paye F, Sauvanet A, et al. Incidence and reversibility of organ failure in the course of sterile or infected necrotizing pancreatitis. Arch Surg 2001; 136: 1386-90.

9 Marshall JC. SIRS and MODS: what is their relevance to the science and practice of intensive care? Shock 2000; 14: 586-9.

10 Zygun DA, Laupland KB, Fick GH, Sandham JD, Doig CJ. Limited ability of SOFA and MOD scores to discriminate outcome: a prospective evaluation in 1,436 patients. Can J Anesth 2005; 52: 302-8.

11 Vincent JL, Moreno R, Takala J, et al. The SOFA (sepsis-related organ failure assessment) score to describe organ dysfunction/failure. On behalf of the Working Group on Sepsis-Related Problems of the European Society of Intensive Care Medicine. Intensive Care Med 1996; 22: 707-10.

12 Marshall JC. A scoring system for the multiple organ dysfunction syndrome (MODS). In: Reinhart K, Eyrich K, Sprung C (Eds). Sepsis: Current Perspectives in Pathophysiology and Therapy. Berlin: SpringerVerlag; 1994: 38-49.

13 Marshall JC, Cook DJ, Christou NV, Bernard GR, Sprung CL, Sibbald WJ. Multiple organ dysfunction score: a reliable descriptor of a complex clinical outcome. Crit Care Med 1995; 23: 1638-52.

14 Knaus WA, Draper EA, Wagner DP, Zimmerman JE. APACHE II: a severity of disease classification system. Crit Care Med 1985; 13: 818-29. 
15 Le Gall JR, Lemeshow S, Saulnier F. A new simplified acute physiology score (SAPS II) based on a European/North American multicenter study. JAMA 1993; 270: 2957-63.

16 Hebert PC, Wells G, Blajchman MA, et al. A multicenter, randomized, controlled clinical trial of transfusion requirements in critical care. Transfusion Requirements in Critical Care Investigators, Canadian Critical Care Trials Group. N Engl J Med 1999; 340: 409-17.

17 Vincent JL, Angus DC, Artigas A, et al. Effects of drotrecogin alfa (activated) on organ dysfunction in the PROWESS trial. Crit Care Med 2003; 31: 834-40.

18 Marshall JC, Panacek EA, Teoh L, Barchuk W.

Modelling organ dysfunction as a risk factor, outcome, and measure of biologic effect in sepsis: results of the MONARCS trial. Crit Care Med 2001; 28: A46 (abstract).

19 Bernard GR, Vincent JL, Laterre PF, et al. Efficacy and safety of recombinant human activated protein $\mathrm{C}$ for severe sepsis. N Engl J Med 2001; 344: 699-709.

20 Brower RG, Matthay MA, Morris A, et al. Ventilation with lower tidal volumes as compared with traditional tidal volumes for acute lung injury and the acute respiratory distress syndrome. N Engl J Med 2000; 342: 1301-8. 